\title{
The physiologic principles of permissive anemia
}

Volume 8 Issue I - 2017

\section{Opinion}

In a recent editorial published in the Journal of Cardiothoracic and Vascular Anesthesia we provided our "opinion piece" on permissive anemia as a safe practice in cardiac surgery. ${ }^{1}$ The concept of permissive anemia is based on the principle that low postoperative hemoglobin (Hb) levels are well tolerated and should not indiscriminately result in red blood cell transfusions. The practice of judiciously accepting a low perioperative $\mathrm{Hb}$ concentration is part of the strategy of blood conservation with the objective of reducing the potential risks of morbidity, mortality, and reduced long-term survival associated with red blood cell transfusions. Countless numbers of studies in the medical and surgical literature argue back and forth on the appropriateness of this clinical practice trying to determine the optimal blood $\mathrm{Hb}$ concentration and indicate the exact number that should trigger a red blood cell transfusion. We argue that this exercise is for the most part unproductive because there is no doubt that higher "natural" $\mathrm{Hb}$ concentration is beneficial to tissue and organ oxygen delivery but there is also no doubt that aiming at a target $\mathrm{Hb}$ concentrations by transfusing red-blood cells can be harmful. ${ }^{2-6}$ Several clinical trials seem to support the practice of permissive anemia in cardiac surgery based on survival benefits and a lower incidence of postoperative complications, nonetheless, the analysis of the scientific principle that could support the use of this practice is broadly underrated. In fact, there is a significant body of basic science research focused on the study of tissue oxygen delivery $\left(\mathrm{DO}_{2}\right)$ and consumption $\left(\mathrm{VO}_{2}\right)$, offering intriguing insights as to the reason why permissive anemia is well tolerated.

In simple terms of cardiovascular physiology, it can be stated that the human circulation is regulated by the body's metabolic requirement. The heart returns in the arterial circulation what it receives as venous return, which is controlled by the metabolic rate of peripheral tissues through a mechanism of chemical flow auto-regulation. ${ }^{7}$ This simple mechanism of peripheral regulation allows adequate $\mathrm{DO}_{2}$ to peripheral tissues based on metabolic requirement, which is measured by $\mathrm{VO}_{2}$. $\mathrm{DO}_{2}$ is function of cardiac output and arterial oxygen content, which in normal physiologic conditions is adjusted to maintain adequate $\mathrm{VO}_{2}{ }^{8}$ However, in any condition causing a drop of the $\mathrm{DO}_{2}$ below a critical level capable of satisfying $\mathrm{VO}_{2}\left(\mathrm{DO}_{2 \text { crit }}\right)$, tissue hypoxia and anaerobic metabolism would develop (anaerobic threshold). ${ }^{24}$ Studies on healthy human subjects in resting conditions have shown that a $\mathrm{DO}_{2}$ of $274 \mathrm{ml} / \mathrm{m}^{2} / \mathrm{min}$ did not produce inadequate tissue oxygenation.9 Further studies have also suggested that $\mathrm{VO}_{2}$ starts declining at much lower levels of $\mathrm{DO}_{2}$, indicating that $\mathrm{DO}_{2 \text { crit }}$ could be at a significantly lower level than previously determined. ${ }^{2}$ Slitight and co-authors determined that under physiologic resting conditions and adequate body oxygenation during the intra and perioperative period, $\mathrm{DO}_{2 \text { crit }}$ in a group of patients undergoing cardiac surgery was never above $196 \mathrm{ml} / \mathrm{m} 2 / \mathrm{min}$, which allowed them to suggest that adequate $\mathrm{DO}_{2}$ could be obtained with $\mathrm{Hb}$ concentration as low as $5.4 \mathrm{gr} / \mathrm{dl}$ in the postoperative cardiac surgery patients. ${ }^{10}$

When values of $\mathrm{DO}_{2 \text { crit }}$ are approached the physiologic mechanisms of homeostasis would implement adjustments aimed at improving

\author{
Domenico Calcaterra,' Aryeh Shander, ${ }^{2}$ \\ Leslie A Renfro 3 \\ 'Minneapolis Research Institute Foundation, USA \\ ${ }^{2}$ Department of Anesthesiology, Englewood Hospital \& Medical \\ Center, USA \\ ${ }^{3}$ Department of Anesthesiology, University of Minnesota, USA
}

Correspondence: Domenico Calcaterra, Minneapolis Heart Institute at Abbott Northwestern Hospital 920 East 28th Street, Suite 400 Minneapolis, MN, 55407, USA, Tel 612.8636895, Fax 612.8636899, Email Domenico.Calcaterra@allina.com

Received: May 22, 2017 | Published: May 24, 2017

$\mathrm{DO}_{2}$ by optimizing tissue perfusion (increasing cardiac output) and $\mathrm{O}_{2}$ extraction, which would be reflected in a reduction of mixed venous oxygen saturation $\left(\mathrm{SvO}_{2}\right)$. If these changes are not sufficient to maintain adequate $\mathrm{DO}_{2}$, whole body $\mathrm{VO}_{2}$ and tissue oxygen saturation begin to decrease causing metabolic (lactic) acidosis. ${ }^{11}$ Nevertheless, when values of $\mathrm{DO}_{2 \text { crit }}$ are approached the delivery of an acceptable whole-body $\mathrm{DO}_{2}$ does not ensure adequate $\mathrm{DO}_{2}$ to all organs. ${ }^{11}$ Studies of $\mathrm{DO}_{2}$ in pigs under cardiopulmonary bypass showed that $\mathrm{DO}_{2}$ to the brain was preserved at the expense of $\mathrm{DO}_{2}$ to other organ systems with significant decrease of $\mathrm{DO}_{2}$ to the splanchnic and muscle circulation. ${ }^{12}$ This finding is confirmed by a large prospective observational study examining the role of $\mathrm{DO}_{2}$ during cardiopulmonary bypass on postoperative renal function, where lower $\mathrm{DO}_{2}$ on bypass (with a critical value of $272 \mathrm{~mL} / \mathrm{m} 2 / \mathrm{min}$ ), versus levels of hematocrit on pump and pump flow rates, represented the best predictor of developing acute renal failure. ${ }^{13}$ Based on these observations we can argue that there is some significant basic science data suggesting that low levels of $\mathrm{Hb}$ are compatible with adequate $\mathrm{DO}_{2}$ under normal physiologic conditions after cardiac surgery and this would suggest that the practice of permissive anemia has a scientific base supporting the results of clinical trials. Of course, we are not, for any possible reason, advocating that hemoglobin concentration of $5 \mathrm{gr} / \mathrm{dl}$ should be indicated as the threshold of a restrictive transfusion practice in cardiac surgery, as anemia could affect $\mathrm{DO}_{2}$ leading to organ injury. Nonetheless, the practice of permissive anemia has substantial support in the studies of the mechanisms of oxygen delivery and consumption, showing that low hemoglobin concentration is well tolerated if $\mathrm{DO}_{2}$ to tissues and organs is maintained above a critical threshold.

\section{Conclusion}

In conclusion, our contention is that "permissive anemia" should not represent a dogmatic practice of "all or nothing". In fact, recommending transfusion of red cells based only on $\mathrm{Hb}$ level when no subjective or objective clinical signs of inadequate $\mathrm{DO}_{2}$ exist may not be in the best interest of the patient. An indiscriminate transfusion practice may expose patients to the potential risks associated with 
red blood cell transfusions when these transfusions are clinically unnecessary. ${ }^{14,15}$ Clinicians must recognize that the patient's condition should dictate the therapy and ought to refrain from the temptation to treat hemoglobin values based simply on a number and with transfusion as the only modality of therapy.

\section{Acknowledgements}

None.

\section{Conflicts of interest}

The authors declare that there is no conflict of interest.

\section{References}

1. Calcaterra D, Renfro LA, Shander A. Navigating the Fine Line Between the Bad and Worse: The Issue Is Not the Number, and the Message Is Not "All or Nothing". J Cardiothorac Vasc Anesth. 2016;30(5):1159-1162.

2. Moskowitz DM, McCullough JN, Shander A, et al. The impact of blood conservation on outcomes in cardiac surgery: is it safe and effective? Ann Thorac Surg. 2010;90(2):451-458.

3. Hajjar LA, Vincent JL, Galas FR, et al. Transfusion requirements after cardiac surgery: the TRACS randomized controlled trial. JAMA. 2010;304(14):1559-1567.

4. Shander AS, Goodnough LT. Blood transfusion as a quality indicator in cardiac surgery. JAMA. 2010;304(14):1610-1611.

5. Ferraris VA, Martin JP. Is limiting transfusion safe? The devil is in the details. J Thorac Cardiovasc Surg. 2015;150(5):1032-1034.

6. Martin JT, Ferraris VA. Blood Conservation. Semin Thorac Cardiovasc Surg. 2015;27(3):266-270.
7. Wolff CB. Normal cardiac output, oxygen delivery and oxygen extraction. Adv Exp Med Biol. 2007;599:169-182.

8. Nichols D, Nielsen ND. Oxygen delivery and consumption: a macrocirculatory perspective. Crit Care Clin. 2010;26(2):239-253.

9. Hong T, Shander A, Agarwal S, et al. Management of a Jehovah's Witness Patient with Sepsis and Profuse Bleeding After Emergency Coronary Artery Bypass Graft Surgery: Rethinking the Critical Threshold of Oxygen Delivery. A Case Rep. 2015;4(10):127-131.

10. Slight RD, Lux D, Nzewi OC, et al. Oxygen delivery and hemoglobin concentration in cardiac surgery: when do we have enough? Artif Organs. 2008;32:949-955

11. Murphy GS, Hessel EA, Groom RC. Optimal perfusion during cardiopulmonary bypass: an evidence-based approach. Anesth Analg. 2009;108(5):1394-1417.

12. Slater JM, Orszulak TA, Cook DJ. Distribution and hierarchy of regional blood flow during hypothermic cardiopulmonary bypass. Ann Thorac Surg. 2001;72(2):542-547.

13. Ranucci $M$, Romitti $F$, Isgrò $G$, et al. Oxygen delivery during cardiopulmonary bypass and acute renal failure after coronary operations. Ann Thorac Surg. 2005;80(6):2213-2220.

14. Najafi M, Faraoni D. Hemoglobin optimization and transfusion strategies in patients undergoing cardiac surgery. World $J$ Cardiol. 2015;7(7):377-382.

15. Vincent JL. Which carries the biggest risk: Anaemia or blood transfusion? Transfus Clin Biol. 2015;22(3):148-150. 